\title{
Trophic Relationships at High Arctic Ice Edges
}

\author{
MICHAEL S. W. BRADSTREET ${ }^{1}$ and WILLIAM E. CROSS ${ }^{1}$
}

\begin{abstract}
At ice edges in the Canadian High Arctic, seabirds and marine mammals eat arctic cod (Boreogadus saida) and, to a lesser extent, zooplankton (calanoid copepods and Parathemisto) and ice-associated amphipods. Cod eat ice-associated amphipods, other ice-associated taxa (harpacticoid and cyclopoid copepods), and zooplankton. Calanoid copepods, Parathemisto, and the ice-associated amphipods studied (Onisimus glacialis, Apherusa glacialis, Gammarus wilkitzkii) all eat primarily diatom algae characteristic of the under-ice flora. From this information, a food web at the ice edge is constructed.
\end{abstract}

Key words: trophic relationships, arctic, ice edges, seabirds, marine mammals, cod, epontic community, zooplankton

RÉSUMÉ. En bordure des glaces dans l'Arctique polaire canadien, les oiseaux de mer et les mammifères marins se nourissent de morue arctiques (Boreogadus saida) et, quoique dans une moindre mesure, de zooplanctons (copépodes calanoides et Parathemisto) et d'amphipodes associés à la glace. La morue se nourrit d'amphipodes ainsi que d'autres taxons (copépodes harpacticoides et cyclopes) tous associés à la glace, et de zooplancton. Les copépodes calanoides Parathemisto, et les amphipodes associés à la glace qui ont été étudiés (Onisimus glacialis, Apherusa glacialis, Gammarus wilkitzkü) tirent tous leur substance principale d'une algue diatomée commune à la flore trouvée sous la glace. A partir de cette information, une chaine alimentaire est donc construite pour la bordure des glaces.

Traduit par Pierre Bibeau, Arkéỏs Inc., Montréal.

\section{INTRODUCTION}

The undersurface of arctic sea ice supports a diverse assemblage and high concentration of microalgae comprised primarily of diatoms (Alexander, 1974; Horner, 1976, 1977; Dunbar and Acreman, 1980). Various invertebrates including meiofauna (nematodes, polychaetes, and harpacticoid and cyclopoid copepods) and macrofauna (primarily gammarid amphipods) live on, or just within, the under-ice surface (e.g., Horner and Alexander, 1972; Golikov and Averincev, 1977). A trophic link between this epontic flora and fauna has been postulated frequently (Apollonio, 1961; English, 1961; Alexander, 1974; Horner, 1977), but quantitative data have been lacking.

A small gadoid fish, the arctic cod (Boreogadus saida), is also thought to occur close to the undersurface of sea ice (Andriashev, 1970; Wilimovsky in McRoy and Goering, 1974; McAllister, 1975; Golikov and Averincev, 1977). As Horner (1976) noted, there are many unpublished observations of cod in close association with blocks of ice overturned by icebreakers. The diet of those specific Boreogadus saida occurring near the ice undersurface has not been studied previously, but this small cod is a major component of the diets of many arctic seabirds and marine mammals (Belopol'skii, 1957; Davis et al., 1980).

During late spring and early summer, many seabirds and marine mammals congregate at the edges of landfast ice in the Canadian High Arctic (Bradstreet, 1979; Finley et al., $1980 ;$ McLaren, 1982). Bradstreet (1980) showed that two alcids occurring at the edges of landfast ice in the Barrow Strait area fed heavily on arctic cod, the pelagic amphipod Parathemisto, and (to a lesser degree) ice-associated amphipods. It seems possible, therefore, that birds and marine mammals congregate at ice edges because feeding opportunities are improved there.

This study was conducted concurrently with those of Bradstreet (1982), who studied the occurrence, distribu- tion, and behavior of seabirds, marine mammals, and arctic cod near the landfast ice edge across the mouth of Pond Inlet in 1979; and Cross (1982), who provided information on under-ice flora and fauna. Here, we integrate the results of these two studies and provide new information on the diets of various vertebrates and invertebrates. This and other information allows us to elucidate important trophic pathways occurring at the edges of landfast ice.

\section{METHODS}

\section{Collection Methods}

Birds. Biologists and Inuit hunters shot actively-feeding birds along the offshore landfast ice edge across Pond Inlet in 1978 (murres [Uria lomvia], $n=63$ ) and 1979 (murres, $n=52$; fulmars [Fulmarus glacialis], $n=31$ ). During dissections (within 12 h of collection) the oesophagus, proventriculus, and gizzard were slit along their combined length and all food items were flushed into storage vials with $10 \%$ neutral formalin.

Mammals. Four ringed seal (Phoca hispida) stomachs were obtained from Inuit hunters at the ice edge. We also collected feces at 13 holes where ringed seals were seen hauled out on the landfast ice $<2 \mathrm{~km}$ from the edge. Stomachs of narwhals (Monodon monoceros) taken by Inuit at the ice edge were available in $1977(n=25)$ and $1979(n=10)$. Stomachs and feces were frozen or preserved in formalin, respectively, for later analysis.

Arctic cod. The stomachs of 46 arctic cod collected from the undersurface of offshore landfast ice $<2 \mathrm{~km}$ from the ice edge and 27 cod from inshore ice cracks near Bylot Island (Bradstreet, 1982) were selected for food habits studies. Fish were frozen in the field for later study. We selected cod representative of the length range within a given year class, and only stomachs that contained food were analyzed. 
Invertebrates. Ten individuals of each of Onisimus glacialis, Gammarus wilkitzkii, and Apherusa glacialis were selected from formalin-preserved diver collections (Cross, 1982) for diet analyses. Also, five zooplankton hauls $(50 \rightarrow 0 \mathrm{~m})$ were made with $239 \mu \mathrm{m}$ mesh, $0.5 \mathrm{~m}$ nets on 7 July 1979 . Small Parathemisto libellula from these zooplankton collections $(1979, n=5)$ and large Parathemisto spp. from murre stomachs $(1978, n=8 ; 1979, n=9)$ were also analyzed. Animals selected were ones that appeared to have food material in their guts. Copepods collected from under the ice edge of Wellington Channel, N.W.T., in June 1976 were also analyzed for food habits.

\section{Analytical Methods}

Analytical methods for bird, arctic cod and ringed seal stomachs were those of Bradstreet (1980). Briefly, food items were identified insofar as was possible, counted, and measured. Total lengths at ingestion of many broken or partially digested items were estimated on the basis of measured parts. Unmeasurable but identified items were assigned average lengths from measured items of the same taxon. Empirically determined relationships between lengths and dry weights were used to convert length-frequency distributions into estimates of the dry weight of each taxon in the diet. Ringed seal feces were sieved; afterwards, these samples were processed in the same manner as seal stomachs.

A dissecting microscope, microscalpel, and pipette were used to dissect amphipods and to remove either the entire gut or its contents to a glass slide. Whole copepods were squashed. A compound microscope was used to scan entire smears at magnifications to $1250 x$. Food items were identified insofar as was possible, and in 1979, a relative abundance code $(1=$ rare, $2=$ few, $3=$ common $)$ was assigned to each food taxon found. Overlap in the diets of amphipods from the Pond Inlet ice edge was determined using Morisita's index ( $\hat{\mathrm{C}} \lambda)$ as modified by Horn (1966) for the

TABLE 1. Per cent composition of fulmar diet at the Pond Inlet ice edge, 1979

\begin{tabular}{|c|c|c|c|}
\hline \multirow[b]{2}{*}{ Taxon } & Occurrence & Frequency & Dry weight \\
\hline & $\begin{array}{c}n=31 \\
\text { stomachs }\end{array}$ & $\begin{array}{c}n=648 \\
\text { items }\end{array}$ & $n=13.6 \mathrm{~g}$ \\
\hline Gadidae & 19.4 & 1.7 & 96.9 \\
\hline Invertebrata & 96.8 & 98.3 & 3.1 \\
\hline Amphipoda & 22.6 & 4.3 & 1.5 \\
\hline Hyperiidae & 12.9 & 0.9 & 0.8 \\
\hline Lysianassidae & 16.1 & 1.5 & 0.6 \\
\hline Calliopiidae & 3.2 & 1.5 & 0.1 \\
\hline Mysidacea & 3.2 & 0.2 & 0.1 \\
\hline Copepoda & 61.3 & 66.9 & 1.1 \\
\hline Decapoda & 6.5 & 0.4 & 0.5 \\
\hline Cephalopoda $^{\mathbf{a}}$ & 87.1 & 26.5 & - \\
\hline Offal $^{\mathrm{b}}$ & 32.3 & - & - \\
\hline
\end{tabular}

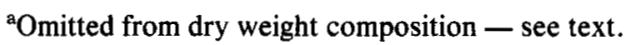

${ }^{b}$ Presence of offal (marine mammal fat) ignored in frequency and dry weight comparisons. relative abundances of various food taxa in the diets of individual amphipods. Overlap in the diet of Parathemisto taken by murres and divers was high $(\hat{C} \lambda=0.92)$; these samples were combined in the computation of overlap values among species.

Numbers, dry weights or sizes of various food taxa in different groups of stomachs are frequently compared statistically. When numbers or dry weights are compared, stomachs containing no items of the food taxon in question are considered, and the number or dry weight of items in a stomach constitutes a unit of observation. When sizes of a food taxon taken by two or more groups are compared, only stomachs containing measured items of the food taxon in question are considered, and the mean length of that taxon in a stomach constitutes a unit of observation. Plus-or-minus values herein are standard deviations.

\section{RESULTS}

\section{Northern Fulmar}

Invertebrates (primarily copepods and cephalopods) were the most common items in the diet of the 31 fulmars

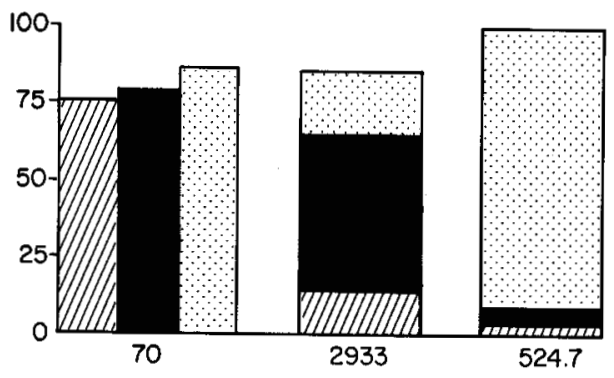

1976

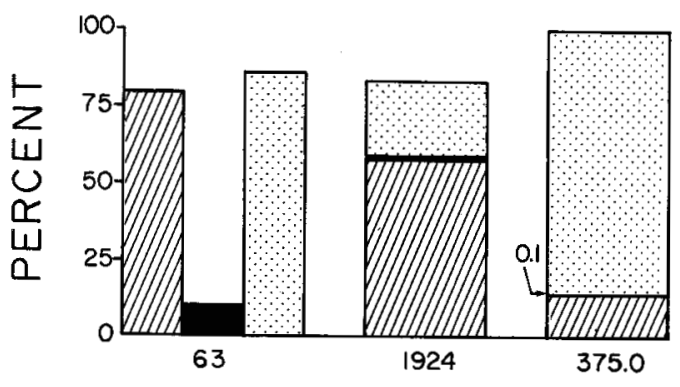

1978

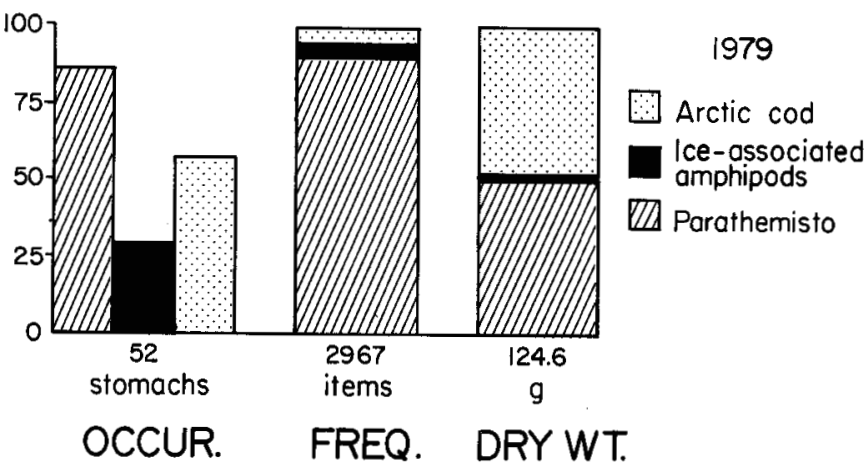

FIG. 1. Percent composition of murre diets in three years. 1976 results are from Bradstreet (1980). 
TABLE 2. Statistical comparisions of three types of prey taken by murres at offshore ice edges in Barrow Strait (1976) and Pond Inlet (1978-79) ${ }^{\mathrm{a}}$

\begin{tabular}{|c|c|c|c|c|c|c|c|c|c|c|c|c|}
\hline \multirow[b]{2}{*}{ Comparison } & \multicolumn{4}{|c|}{ All Parathemisto } & \multicolumn{4}{|c|}{ Ice-associated amphipods ${ }^{\mathrm{b}}$} & \multicolumn{4}{|c|}{ Arctic cod } \\
\hline & Numbers & $\begin{array}{l}\text { Dry weight } \\
\text { (mg) }\end{array}$ & $\begin{array}{c}\text { Mean length } \\
(\mathrm{mm})\end{array}$ & $n^{\mathrm{c}}$ & Numbers & $\begin{array}{l}\text { Dry weight } \\
\text { (mg) }\end{array}$ & $\begin{array}{c}\text { Mean length } \\
(\mathrm{mm})\end{array}$ & $n^{\mathrm{c}}$ & Numbers & $\begin{array}{c}\text { Dry weight } \\
\text { (mg) }\end{array}$ & $\begin{array}{c}\text { Mean length } \\
(\mathrm{mm})\end{array}$ & $n^{\mathrm{e}}$ \\
\hline 1978 smooth ice edge & $28.3 \pm 26.0^{d}$ & $1271 \pm 1059$ & $29.7 \pm 2.7$ & $22(22)$ & $0.1 \pm 0.5$ & $3 \pm 12$ & $15.8 \pm 7.4$ & $22(2)$ & $4.2 \pm 5.2$ & $2761 \pm 5170$ & $70.8 \pm 12.5$ & $22(17)$ \\
\hline 1978 rough ice edge & $19.9 \pm 25.9$ & $811 \pm 922$ & $29.7 \pm 2.9$ & $12(11)$ & $0.6 \pm 1.2$ & $40 \pm 82$ & $35.8 \pm 3.8$ & $12(3)$ & $6.3 \pm 6.1$ & $4236 \pm 6282$ & $68.9 \pm 9.8$ & $12(10)$ \\
\hline Mann-Whitney statistic ${ }^{e}$ & 1.35 & 1.51 & 0.06 & & 1.32 & 1.40 & - & & 1.04 & 0.92 & (78) & \\
\hline$P$ & 0.18 & 0.13 & 0.95 & & 0.19 & 0.16 & - & & 0.36 & 0.36 & $>0.1$ & \\
\hline 1979 smooth ice edge & $69.4 \pm 57.5$ & $1635 \pm 1480$ & $21.5 \pm 5.0$ & $25(22)$ & $4.7 \pm 16.2$ & $48 \pm 101$ & $15.7 \pm 8.9$ & $26(13)$ & $2.0 \pm 3.6$ & $848 \pm 1729$ & $50.8 \pm 31.7$ & $25(13)$ \\
\hline 1979 rough ice edge & $107.8 \pm 36.7$ & $2107 \pm 648$ & $21.6 \pm 0.4$ & 4 (4) & $0.2 \pm 0.4$ & $13 \pm 29$ & 19.5 & $5(1)$ & $0.5 \pm 1.0$ & $357 \pm 714$ & 85.0 & $4(1)$ \\
\hline Mann-Whitney statistic ${ }^{e}$ & 1.58 & 0.95 & 1.10 & & 1.54 & 1.15 & - & & 0.89 & 0.75 & - & \\
\hline$P$ & 0.11 & 0.34 & 0.27 & & 0.12 & 0.25 & - & & 0.37 & 0.45 & 一 & \\
\hline 1976 offshore ice edges & $5.9 \pm 6.9$ & $134 \pm 181$ & $20.9 \pm 5.4$ & $70(54)$ & $21.3 \pm 50.8$ & $153 \pm 316$ & $13.1 \pm 5.8$ & $70(54)$ & $8.8 \pm 8.9$ & $7170 \pm 8147$ & $81.4 \pm 28.9$ & $70(60)$ \\
\hline 1978 offshore ice edges & $17.5 \pm 22.8$ & $794 \pm 959$ & $29.8 \pm 2.8$ & $63(49)$ & $0.2 \pm 0.6$ & $9 \pm 38$ & $24.9 \pm 12.8$ & $63(6)$ & $6.5 \pm 7.0$ & $5132 \pm 7047$ & $73.9 \pm 13.4$ & $64(54)$ \\
\hline 1979 offshore ice edges & $54.4 \pm 52.2$ & $1269 \pm 1266$ & $22.9 \pm 2.0$ & $54(44)$ & $2.3 \pm 11.4$ & $25 \pm 73$ & $15.7 \pm 8.2$ & $54(16)$ & $2.5 \pm 4.9$ & $1124 \pm 2526$ & $67.2 \pm 17.9$ & $54(24)$ \\
\hline Kruskal-Wallis $H$ & 35.5 & 39.5 & 85.2 & & 73.6 & 66.1 & 5.6 & & 33.2 & 38.9 & 2.6 & \\
\hline$P$ & $<0.001$ & $<0.001$ & $<0.001$ & & $<0.001$ & $<0.001$ & $<0.02$ & & $<0.001$ & $<0.001$ & $>0.1$ & \\
\hline
\end{tabular}

a 1976 data are from Brađstreet (1980 and unpublished)

bice-associated amphipods include the following genera: Onisimus, Gammarus, Apherusa, Ischyrocerus, and Gammaracanthus.

'In numerical and dry weight comparisons, $n=$ number of stomachs examined. In length comparisons, $(n)=$ number of stomachs containing measurable items of taxon under consideration.

dMean \pm standard deviation

${ }^{\text {' }}$ Test statistic is Mann-Whitney $U$ (in parentheses) when $n$ for both samples $<20$; test statistic is Mann-Whitney $z$ when either $n \geqslant 20$. Probabilities are two-tailed.

collected (Table 1). Cephalopods were represented solely by beaks. The otoliths and flesh of one cod (estimated as $100-110 \mathrm{~mm}$ fork length) were found in one stomach. Other fish remains (eye lenses, flesh, bones) were found in five stomachs and were estimated to represent eight fish. These nine cod, if recently ingested, dominated (97\%) the dry weight diet of collected fulmars. If only the one fish represented by otoliths had been ingested recently, cod accounted for $78 \%$ of the dry weight and copepods and amphipods accounted for $8 \%$ and $11 \%$, respectively. Ten of the fulmars collected had scavenged marine mammal carcasses. The stomachs of some of these birds contained much animal fat, but it was impossible to consider this fat in dry weight analyses.

\section{Thick-billed Murre}

Arctic cod, Parathemisto, and (to a lesser degree) iceassociated amphipods dominated the diet of the murres collected along offshore landfast ice edges in 1978 and 1979 (Fig. 1). Cod dominated the dry weight of stomach contents in 1978, and cod and Parathemisto were codominant in 1979. The mean estimated dry weights of total stomach contents in murres decreased from 1978 $(6.0 \pm 7.0 \mathrm{~g})$ to $1979(2.4 \pm 2.6 \mathrm{~g}$; Mann-Whitney $P=0.002)$.

Smooth and rough ice occurred at the Pond Inlet ice edge in both years, but neither numbers nor dry weights of cod or ice-associated amphipods were significantly different in murres collected near the two ice types (Table 2). Furthermore, numbers and dry weights of the pelagic amphipod Parathemisto taken by murres in these two habitats were also similar.

\section{Ringed Seal}

Feces collected at seal holes near the ice edge contained mostly arctic cod otoliths. Fish represented by these otoliths occurred in $92 \%$ of the feces, comprised $92 \%$ of the food items, and formed more than $99.9 \%$ of diet dry weight. Copepods occurred in 11 of 13 samples in low numbers (6\% frequency), and larger invertebrates (Parathemisto, Onisimus, Gammarus) occurred in fewer samples (1 or 2) in very small numbers (the three genera totalled 5 of 303 items enumerated). Along the ice edge in 1979, the cod represented by otoliths in seal feces (mean length $102 \pm 16 \mathrm{~mm}$ ) were significantly larger than those represented in murre stomach tracts $(67 \pm 18 \mathrm{~mm}$; Mann-Whitney $P<0.001)$.

The stomach contents of four immature seals shot while they were swimming near the ice edge were very different from the diet (as determined from feces) of older seals hauled out on the ice. The diet of these immature seals (based on 1094 food items with an estimated dry weight at ingestion of $67.4 \mathrm{~g}$ ) was dominated by amphipods ( $96 \%$ of numbers, $38 \%$ of dry weight) and cod (2.6\% of numbers, $62 \%$ of dry weight). Most of the amphipods were Parathemisto (84\%), and both Boreogadus saida and Arctogadus glacialis occurred in the stomachs.

\section{Narwhal}

In each year at the ice edge, arctic cod of similar size (114 $\pm 33 \mathrm{~mm} ; n=8242$ cod in 33 of 35 stomachs) formed the bulk of the wet weight diet of narwhals. There was a marginal decrease (Mann-Whitney $P=0.07$ ) in the perstomach wet weight contents of arctic cod from 1978 to 1979. Narwhals also took polar cod (Arctogadus glacialis), 
TABLE 3. Percent composition of the diets of various age classes of arctic cod at offshore and inshore locations near the Pond Inlet ice edge in 1979

\begin{tabular}{|c|c|c|c|c|c|c|c|c|c|c|c|c|}
\hline \multirow[b]{2}{*}{ Food taxon } & \multicolumn{3}{|c|}{ Offshore cod } & \multicolumn{3}{|c|}{ Inshore cod } & \multicolumn{3}{|c|}{ Offshore cod } & \multicolumn{3}{|c|}{ Inshore cod } \\
\hline & Occur. & Freq. & Dry wt. & Occur. & Freq. & Dry wt. & Occur. & Freq. & Dry wt. & Occur. & Freq. & Dry wt. \\
\hline & \multicolumn{6}{|c|}{ One-year-old } & \multicolumn{6}{|c|}{ Three-year-old } \\
\hline Copepoda & 100.0 & 98.2 & 73.2 & 100.0 & 97.9 & 99.8 & 100.0 & 99.7 & 95.0 & 100.0 & 94.4 & 52.6 \\
\hline Calanoida & 100.0 & 59.8 & 82.2 & 100.0 & 53.5 & 97.5 & 100.0 & 99.3 & 95.0 & 100.0 & 94.3 & 52.6 \\
\hline Harpacticoida & 18.2 & 29.2 & 3.0 & 66.7 & 43.0 & 2.3 & 14.3 & 0.5 & $<0.05$ & 11.1 & 0.1 & $<0.05$ \\
\hline Cyclopoida & 22.7 & 9.2 & $<0.05$ & 33.3 & 1.4 & $<0.05$ & - & - & - & - & - & - \\
\hline Amphipoda & 22.7 & 1.5 & 13.7 & 33.3 & 2.1 & 0.2 & 28.6 & 0.2 & 4.8 & 100.0 & 5.2 & 44.6 \\
\hline Parathemisto spp. & 9.1 & 1.1 & 2.8 & - & - & - & 14.3 & 0.1 & 0.1 & 33.3 & $<0.04$ & 3.2 \\
\hline Onisimus spp. & 4.5 & 0.1 & 7.6 & - & - & - & 14.3 & 0.1 & 4.6 & 44.4 & 1.1 & 13.2 \\
\hline Gammarus spp. & - & - & - & 33.3 & 2.1 & 0.2 & - & - & - & 33.3 & 0.1 & 4.0 \\
\hline Ischyrocerus spp. & - & - & - & - & - & - & - & - & - & 22.2 & 1.3 & 12.1 \\
\hline Apherusa glacialis & 9.1 & 0.2 & 3.3 & - & - & - & - & - & - & - & - & - \\
\hline Ostracoda & 4.5 & 0.2 & $<0.05$ & - & - & - & - & - & - & - & - & - \\
\hline Mysidacea & - & - & - & - & - & - & - & - & - & 11.1 & 0.1 & 2.8 \\
\hline Chaetognatha & - & - & - & - & - & - & - & - & - & 22.2 & 0.3 & 4.0 \\
\hline \multirow[t]{2}{*}{ Sample sizes ${ }^{\mathrm{a}}$} & 22 & 826 & 39.5 & 3 & 142 & 13.2 & 7 & 1111 & 151.0 & 9 & 1309 & 576.8 \\
\hline & \multicolumn{6}{|c|}{ Two-year-old } & \multicolumn{6}{|c|}{ All age classes ${ }^{b}$} \\
\hline Copepoda & 87.5 & 77.1 & 45.7 & 100.0 & 98.8 & 95.6 & 95.7 & 93.3 & 72.8 & 100.0 & 95.9 & 61.0 \\
\hline Calanoida & 87.5 & 76.9 & 45.7 & 100.0 & 78.9 & 95.0 & 95.7 & 81.8 & 72.5 & 100.0 & 82.6 & 60.8 \\
\hline Harpacticoida & 6.3 & 0.1 & $<0.05$ & 15.4 & 19.7 & 0.6 & 13.0 & 8.8 & 0.3 & 18.5 & 13.2 & 0.4 \\
\hline Cyclopoida & - & - & - & 7.7 & 0.1 & $<0.05$ & 10.9 & 2.7 & $<0.05$ & 7.4 & 0.1 & $<0.05$ \\
\hline Amphipoda & 62.5 & 22.7 & 42.4 & 46.2 & 1.2 & 4.5 & 39.1 & 6.5 & 21.7 & 66.7 & 3.9 & 36.1 \\
\hline Parathemisto spp. & 62.5 & 22.0 & 41.6 & 7.7 & 0.2 & $<0.05$ & 28.3 & 6.2 & 18.6 & 14.8 & 0.2 & 1.7 \\
\hline Onisimus spp. & - & - & - & - & - & - & 4.3 & 0.1 & 2.5 & 18.5 & 0.5 & 11.3 \\
\hline Gammarus spp. & - & - & - & 23.1 & $<0.05$ & 0.1 & - & - & - & 25.9 & 1.5 & 8.0 \\
\hline Ischyrocerus spp. & - & - & - & 7.7 & $<0.05$ & 1.1 & - & - & - & 18.5 & 0.5 & 7.7 \\
\hline Apherusa glacialis & 12.5 & 0.3 & 0.3 & - & - & - & 8.7 & 0.1 & 0.5 & - & - & - \\
\hline Ostracoda & - & - & - & - & - & - & 2.2 & 0.1 & $<0.05$ & - & - & - \\
\hline Mysidacea & - & - & - & - & - & - & 2.2 & $<0.05$ & 5.2 & 7.4 & 0.1 & 2.9 \\
\hline Chaetognatha & - & - & - & 7.7 & $<0.05$ & $<0.05$ & - & - & - & 11.1 & 0.1 & $<0.05$ \\
\hline Sample sizes ${ }^{\mathrm{a}}$ & 16 & 746 & 178.4 & 13 & 2152 & 373.1 & 46 & 2817 & 406.6 & 27 & 3703 & 1115.9 \\
\hline
\end{tabular}

${ }^{\text {a}}$ Sample sizes as follows: occurrence $=$ number of non-empty stomachs analyzed; frequency = no. food items enumerated; dry weight = no. mg dry weight estimated for the time of ingestion. Values in table are percentages based on these sample sizes.

bIncludes four-year-old cod from offshore $(n=1)$ and inshore $(n=2)$ collections.

squid, Greenland halibut (Reinhardtius hippoglossoides), other fish, and pelagic crustaceans (Boreomysis spp., Hymenodora decapods).

\section{Arctic Cod}

Copepods and amphipods dominated the diet of the cod examined, regardless of the age class of the fish or collection location (Table 3). Considering all age classes together, copepods occurred in almost all stomachs examined, in large numbers, and comprised the majority of the dry weight diet. Although amphipods occurred in relatively low numbers, the large individual size of the amphipods ingested (when compared to copepods) meant that this taxon was second in importance in terms of dry weight. Mysids were third in dry weight importance; ostracods and chaetognaths were taken by few cod.

Cod taken near shore contained greater numbers and dry weights of copepods and amphipods per stomach than did cod taken offshore (Table 4). Amphipods appeared to be of greater relative importance to cod from inshore than from offshore areas: amphipods occurred in $39 \%$ of the offshore cod and $67 \%$ of the inshore cod, and the ratio of mean amphipod dry weight per stomach : mean copepod dry weight per stomach was twice as large for inshore (0.6) as for offshore (0.3) arctic cod. Gammarus spp., Onisimus spp., and Ischyrocerus spp. dominated the amphipods from inshore cod, whereas Parathemisto spp. dominated those from offshore cod.

Greater weights of amphipods occurred in older than in younger inshore cod, but this was not apparent in offshore cod (Table 4). Harpacticoid and cyclopoid copepods occurred in greater numbers in one-year-old than in older cod collected in both offshore and inshore locations (Table 3). In offshore fish the mean lengths of ingested copepods were significantly correlated with fish length (Fig. 2). This was also the case for amphipods in inshore fish, but not for amphipods in offshore or copepods in inshore cod. There was further evidence of size selection in feeding of offshore cod: adult copepods (Calanus glacialis and Calanus 
TABLE 4. Statistical comparisons of two prey taxa taken by arctic cod at offshore and inshore locations

All copepods All amphipods

\begin{tabular}{|c|c|c|c|c|c|c|c|c|}
\hline Group & Number & $\begin{array}{c}\text { Dry weight } \\
\text { (mg) }\end{array}$ & $\begin{array}{c}\text { Length } \\
\text { (mm) }\end{array}$ & $n^{\mathrm{a}}$ & Number & $\begin{array}{c}\text { Dry weight } \\
(\mathrm{mg})\end{array}$ & $\begin{array}{c}\text { Length } \\
(\mathrm{mm})\end{array}$ & $n^{\mathrm{a}}$ \\
\hline $\begin{array}{l}\text { Offshore } 1 \text { yr cod } \\
\text { Inshore } 1 \text { yr cod }\end{array}$ & $\begin{array}{c}36.8 \pm 57.6^{\mathrm{b}} \\
46.3 \pm 43.0\end{array}$ & $\begin{array}{l}1.5 \pm 1.8 \\
4.4 \pm 6.8\end{array}$ & $\begin{array}{c}2.9 \pm 2.0 \\
4.2\end{array}$ & $\begin{array}{c}22(20) \\
3(1)\end{array}$ & $\begin{array}{l}0.5 \pm 1.7 \\
1.0 \pm 1.7\end{array}$ & $\begin{array}{c}0.2 \pm 0.7 \\
0.1\end{array}$ & $\begin{array}{c}5.6 \pm 2.3 \\
1.5\end{array}$ & $\begin{array}{r}22(4) \\
3(1)\end{array}$ \\
\hline $\begin{array}{l}\text { Offshore } 2 \text { yr cod } \\
\text { Inshore } 2 \text { yr cod }\end{array}$ & $\begin{array}{r}35.9 \pm 38.0 \\
163.6 \pm 177.9\end{array}$ & $\begin{array}{r}5.1 \pm 5.8 \\
27.4 \pm 22.2\end{array}$ & $\begin{array}{l}4.1 \pm 1.0 \\
5.4 \pm 1.4\end{array}$ & $\begin{array}{l}16(13) \\
13(13)\end{array}$ & $\begin{array}{r}10.6 \pm 34.9 \\
1.9 \pm 3.2\end{array}$ & $\begin{array}{l}4.7 \pm 12.0 \\
1.1 \pm 1.7\end{array}$ & $\begin{array}{l}8.1 \pm 4.4 \\
3.5 \pm 1.9\end{array}$ & $\begin{array}{l}16(8) \\
13(3)\end{array}$ \\
\hline $\begin{array}{l}\text { Offshore } 3 \text { yr cod } \\
\text { Inshore } 3 \text { yr cod }\end{array}$ & $\begin{array}{l}158.3 \pm 112.9 \\
137.3 \pm 101.0\end{array}$ & $\begin{array}{l}20.5 \pm 12.9 \\
33.7 \pm 26.0\end{array}$ & $\begin{array}{l}4.7 \pm 0.9 \\
5.8 \pm 1.0\end{array}$ & $\begin{array}{l}7(7) \\
9(8)\end{array}$ & $\begin{array}{l}0.3 \pm 0.5 \\
7.6 \pm 5.3\end{array}$ & $\begin{array}{r}1.0 \pm 2.6 \\
28.6 \pm 23.4 \\
\end{array}$ & $\begin{array}{c}4.5 \\
9.7 \pm 3.3 \\
\end{array}$ & $\begin{array}{l}7(1) \\
9(8) \\
\end{array}$ \\
\hline $\begin{array}{l}\text { All offshore cod } \\
\text { All inshore cod } \\
\text { Mann-Whitney statistic } \\
\quad P\end{array}$ & $\begin{array}{c}57.1 \pm 76.2 \\
131.5 \pm 141.8 \\
2.88 \\
0.004\end{array}$ & $\begin{array}{r}6.4 \pm 10.0 \\
25.2 \pm 23.5 \\
3.80 \\
<0.001\end{array}$ & $\begin{array}{c}3.6 \pm 1.8 \\
5.4 \pm 1.2 \\
4.31 \\
<0.001\end{array}$ & $\begin{array}{l}46(41) \\
27(24)\end{array}$ & $\begin{array}{l}4.0 \pm 20.7 \\
5.3 \pm 8.1 \\
3.08 \\
0.002\end{array}$ & $\begin{aligned} & 1.9 \pm 7.3 \\
& 14.8 \pm 23.3 \\
& 2.82 \\
& 0.005\end{aligned}$ & $\begin{array}{c}7.5 \pm 3.8 \\
7.9 \pm 4.2 \\
(83) \\
>0.1\end{array}$ & $\begin{array}{l}46(13) \\
27(14)\end{array}$ \\
\hline
\end{tabular}

${ }^{2}$ In numerical and dry weight comparisons, $n=$ number of stomachs examined. In length comparisons, $(n)=$ number of stomachs containing measurable items of taxon under consideration.

${ }^{b}$ Mean \pm standard deviation.

'Test statistic is Mann-Whitney $U$ (in parentheses) when $n$ for both samples $<20$; test statistic is Mann-Whitney $z$ when either $n \geqslant 20$.

Probabilities are two-tailed.

hyperboreus) were more numerous than smaller copepodite stages in stomach contents, whereas in zooplankton samples copepodites occurred much more frequently than did adults (Fig. 3). In contrast, there was some evidence that offshore cod selected smaller individuals of the amphipod Parathemisto (Fig. 3).

\section{Invertebrates}

The four amphipod species and three copepod species studied all consumed microalgae, and crustacean parts were also present in the gut contents of the amphipods Gammarus wilkitzkii and Parathemisto spp. (Tables 5-7). The algal diet of each species was dominated by pennate diatoms of the genera Nitzschia and Navicula, both in terms of numbers of species and relative abundance. Nitzschia frigida and Nitzschia grunowii were dominant in 1979 samples.

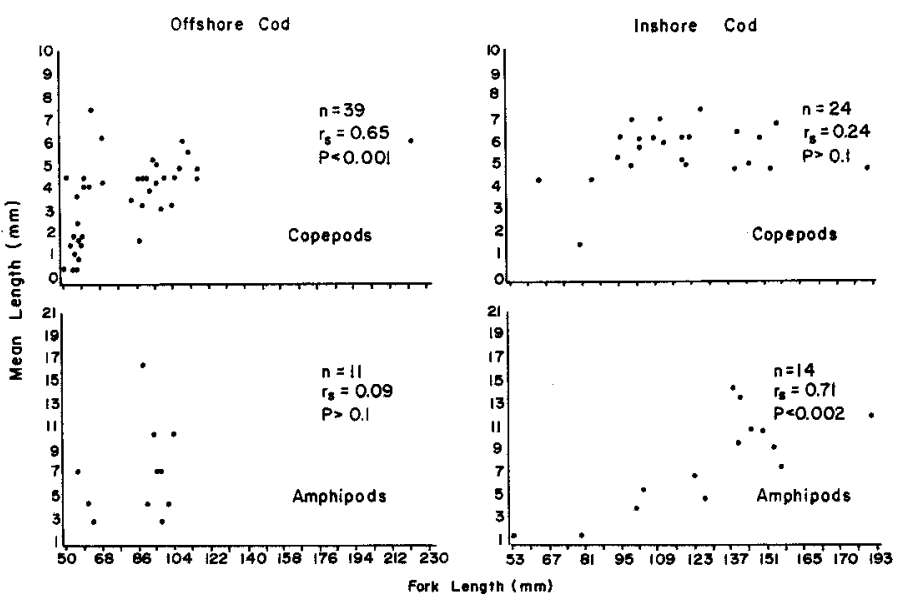

FIG. 2. Prey length (copepods above, amphipods below) vs. arctic cod length for cod from offshore and inshore locations in Pond Inlet, 1979.
Centric diatoms, filamentous algae and microflagellates were also present in the diets of some species.

The diet of Onisimus glacialis consisted entirely of diatoms and included more species $(25+)$ in higher abun-
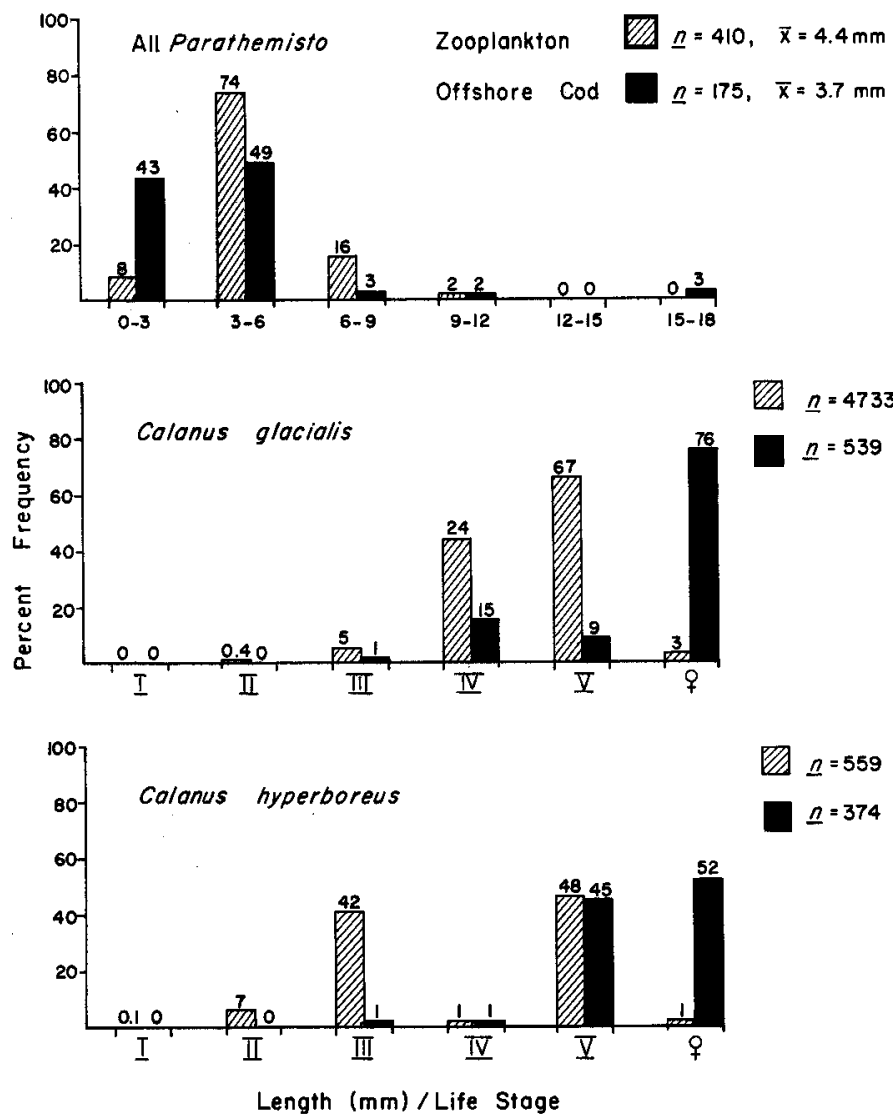

FIG. 3. Sizes of selected taxa in zooplankton and in the diets of offshore cod. Based on the diets of $47 \mathrm{cod}$ and on five zooplankton hauls $(50 \rightarrow 0 \mathrm{~m})$ made with $239 \mu \mathrm{m}$ mesh, $0.5 \mathrm{~m}$ nets on 7 July 1979. 
TABLE 5. Diet of ice-associated amphipods along the Pond Inlet ice edge, 1979

\begin{tabular}{|c|c|c|c|c|c|c|}
\hline \multirow{2}{*}{ Food taxon } & \multicolumn{2}{|c|}{ Onisimus glacialis } & \multicolumn{2}{|c|}{ Apherusa glacialis } & \multicolumn{2}{|c|}{ Gammarus wilkitzkii } \\
\hline & $\begin{array}{l}\text { No. stomachs } \\
(n=10)\end{array}$ & Total importance $^{a}$ & $\begin{array}{c}\text { No. stomachs } \\
(n=10)\end{array}$ & Total importance ${ }^{\mathrm{a}}$ & $\begin{array}{l}\text { No. stomachs } \\
\quad(n=10)\end{array}$ & Total importance ${ }^{a}$ \\
\hline \multicolumn{7}{|l|}{ Pennate Diatoms } \\
\hline Amphiprora spp. & 4 & 5 & - & - & - & - \\
\hline Amphora spp. & 7 & 8 & 2 & 2 & - & - \\
\hline Diploneis littoralis & 1 & 1 & - & - & - & - \\
\hline Gomphonema exiguum & 2 & 2 & - & - & - & - \\
\hline Licmophora spp. & 2 & 2 & - & - & 3 & 3 \\
\hline Navicula directa & 3 & 3 & - & - & - & - \\
\hline$"$ forcipata & 4 & 4 & - & - & - & - \\
\hline " gelida & 3 & 4 & - & - & - & \\
\hline " quadripedis & 1 & 1 & - & - & - & - \\
\hline$" \quad$ salinarum & 4 & 5 & - & - & - & - \\
\hline " vanhoeffenii & 1 & 1 & - & - & - & - \\
\hline " spp. & 7 & 13 & 6 & 6 & 5 & 6 \\
\hline Nitzschia angularis & 8 & 13 & - & - & - & - \\
\hline$" \quad$ cylindrus & 8 & 15 & 1 & 1 & 1 & 1 \\
\hline " delicatissima & 8 & 12 & - & - & 1 & 1 \\
\hline "distans & 1 & 1 & - & - & - & - \\
\hline " frigida & 10 & 25 & 3 & 3 & 4 & 4 \\
\hline " grunowii & 10 & 20 & 1 & 1 & 4 & 5 \\
\hline " longissima & 9 & 10 & - & - & 1 & 1 \\
\hline " seriata & - & - & 1 & 1 & - & - \\
\hline " sigma & 5 & 5 & - & - & - & - \\
\hline " spp. & 3 & 5 & 8 & 9 & 2 & 2 \\
\hline Pinnularia quadrata & 3 & 4 & - & - & - & - \\
\hline " spp. & 2 & 2 & - & - & - & - \\
\hline Pleurosigma angulatum & 1 & 1 & - & - & 1 & 1 \\
\hline$" \quad$ elongatum & 1 & 1 & - & - & - & - \\
\hline$" \quad$ spp. & 7 & 7 & - & - & - & - \\
\hline Rhoicosphernia curvata & 1 & 1 & - & - & - & - \\
\hline \multicolumn{7}{|l|}{ Centric Diatoms } \\
\hline Chaetoceros septentrionalis & 2 & 2 & - & - & - & - \\
\hline$"$ spp. & 2 & 2 & 1 & 1 & 1 & 1 \\
\hline Filamentous alga & - & - & 1 & 1 & 1 & 1 \\
\hline Microflagellates & - & - & 4 & 5 & 3 & 3 \\
\hline Crustacean parts & - & - & - & - & 5 & 5 \\
\hline
\end{tabular}

${ }^{\text {a}}$ Food taxon abundance in each stomach ranked as follows: $1=$ rare, 2 = few, $3=$ common. Total importance is sum of abundance ranks.

dances than did that of the other amphipod species (Table 5). Apherusa glacialis and G. wilkitzkii consumed similar numbers of diatom species and individuals and their diets also included microflagellates and filamentous algae (Table 5). Parathemisto consumed relatively fewer algae, and crustaceans were relatively more important in its diet (Table 6). Diet overlap was higher between Parathemisto and $G$. wilkitzkii $(\hat{\mathrm{C}} \lambda=0.76)$ than between either of these taxa and other species $(\hat{C} \lambda=0.42$ to 0.63 ), probably because these two large amphipods took crustaceans as food. The diets of $A$. glacialis and $O$. glacialis were relatively dissimilar ( $\hat{\mathrm{C}} \lambda=0.39$ ), likely because of the larger number of species that $O$. glacialis utilized.
The diet of Calanus hyperboreus included the highest number of algal species (14) among the copepods examined, and contained microflagellates as well as pennate and centric diatoms. Calanus glacialis fed on diatoms alone (10 species) and Pseudocalanus spp. consumed only three species of pennate diatoms (Table 7).

\section{DISCUSSION}

The central position of arctic cod in the transfer of energy from lower to higher levels in the food chain is obvious - cod were of major importance in the diets of five of the six birds and mammals studied (Fig. 4). Selected 
TABLE 6. Diet of Parathemisto spp. amphipods along the Pond Inlet ice edge in 1978 and 1979

1978

$1979^{\mathrm{a}}$

\begin{tabular}{|c|c|c|c|c|c|c|}
\hline \multirow{2}{*}{ Food taxon } & \multirow{2}{*}{$\begin{array}{c}\text { From murre stomachs }(n=8) \\
\begin{array}{c}\text { No. } \\
\text { stomachs }\end{array} \\
\end{array}$} & \multicolumn{2}{|c|}{ From murre stomachs $(n=5)$} & \multicolumn{2}{|c|}{ zooplankton $(n=5)$} & \multirow{2}{*}{$\begin{array}{c}\text { All years } \\
(n=27) \\
\% \\
\text { occurrence }\end{array}$} \\
\hline & & $\begin{array}{c}\text { No. } \\
\text { stomachs }\end{array}$ & $\begin{array}{c}\text { Total } \\
\text { importance }\end{array}$ & $\begin{array}{c}\text { No. } \\
\text { stomachs }\end{array}$ & $\begin{array}{c}\text { Total } \\
\text { importance }\end{array}$ & \\
\hline \multicolumn{7}{|l|}{ Pennate Diatoms } \\
\hline Achnanthes taeniata & 1 & - & - & - & - & 4 \\
\hline Amphora spp. & 1 & - & - & - & 一 & 4 \\
\hline Navicula ${ }^{c}$ & 2 & 3 & 4 & 2 & 2 & 30 \\
\hline$N$. forcipata & - & 1 & 1 & - & - & 4 \\
\hline N. salinarum & - & 1 & 1 & - & - & 4 \\
\hline Nitzschia ${ }^{c}$ & 5 & 5 & 10 & 4 & 9 & 85 \\
\hline N. cylindrus & 2 & - & - & - & - & 11 \\
\hline N. frigida & 1 & 2 & 3 & 1 & 2 & 26 \\
\hline N. grunowii & 3 & 2 & 2 & 4 & 4 & 70 \\
\hline N. longissima & - & 1 & 1 & - & - & 4 \\
\hline$N$. seriata & 1 & - & - & - & - & 22 \\
\hline Pleurosigma spp. & 1 & 1 & 1 & - & - & 7 \\
\hline \multicolumn{7}{|l|}{ Centric Diatoms } \\
\hline Melosira arctica & 1 & - & - & - & - & 4 \\
\hline Crustacean parts & 8 & 5 & 6 & 4 & 5 & 70 \\
\hline
\end{tabular}

${ }^{a}$ In 1979 , food taxon abundance in each stomach ranked as follows: $1=$ rare, $2=$ few, 3 = common. Total importance is sum of abundance ranks.

bIncludes data from nine Parathemisto collected at the Wellington Channel ice edge in July 1976 (Bain et al., 1977).

'Includes unidentified species.

major food taxa in diets of seabirds and marine mammals had similar standardized energy values - range 5.4-6.5 $\mathrm{kcal}^{-1} \mathrm{~g}^{-1}$ (dry weight basis). However, the numbers of food items that must be captured to provide $100 \mathrm{kcal}$ of energy varied, from 12-32 in the case of arctic cod and up to 34500 in the case of calanoid copepods (Table 8). This fact in itself probably largely explains the central position of arctic cod in the transfer of energy from lower to higher trophic levels. The food habits of any predator are, however, a result of many factors, an important one being the relationship between energy expenditure while feeding and energy return from feeding. The expenditure : return ratio in itself involves a complex set of interactions among numerous variables including the relative availability and accessibility of various food taxa, the capabilities of individual predators, and the energetic (and other) qualities of various food items.

Although arctic cod dominated the diets of most seabirds and marine mammals that were studied, other taxa were also consumed. Higher vertebrates at the Pond Inlet ice edge in 1978 and 1979 ate mainly calanoid copepods, Parathemisto, and arctic cod in various combinations.

\section{Seabird Diets}

Fulmars are well known to have an omnivorous diet (e.g. Salomonsen, 1950; Fisher, 1952). Stomach contents and behavior at the Pond Inlet ice edge suggest that there, as elsewhere, fulmars are mainly visual predators taking small crustaceans and fish from surface or near-surface waters. Cephalopod beaks were common in our samples, but because these beaks are known to remain for considerable periods of time in bird stomachs (Clarke, 1962) and because no squid flesh was found, squid probably were not important in the diet of fulmars at the ice edge ( $c f$. Hagerup, 1926; Palmer, 1962). Fulmars also scavenged marine mammal carcasses when available (Bradstreet, 1982).

Thick-billed murres consumed arctic cod, Parathemisto, and ice-associated amphipods. In Barrow Strait in 1976 arctic cod dominated the dry weight diet of murres (Bradstreet, 1980), but from 1976 to 1978 to 1979, the numbers and dry weight of cod per murre stomach decreased significantly (Table 2, Fig. 1). The mean lengths of cod in the stomachs did not vary among years. A small relative decrease in the dry weight importance of cod from 1976 (96\%) to $1978(86 \%)$ was apparently compensated for mainly by increased use of more and larger Parathemisto (Table 2), since there were no significant differences in the mean estimated dry weights of total stomach contents in murres from the two years $(1976=7.5 \pm 2.8 \mathrm{~g}$, (Bradstreet, unpubl. data); Mann-Whitney $P=0.4$ ). In addition to arctic cod, ice-associated amphipods occurred in smaller numbers and dry weights in 1978 than in 1976, but like 
TABLE 7. Percent occurrence of algae in the stomachs of calanoid copepods in June ${ }^{a}$

\begin{tabular}{|c|c|c|c|}
\hline Taxon & $\begin{array}{c}\text { Calanus } \\
\text { hyperboreus } \\
n=27^{\mathrm{b}} \\
\end{array}$ & $\begin{array}{l}\text { Calanus } \\
\text { glacialis } \\
n=30^{c}\end{array}$ & $\begin{array}{l}\text { Pseudocalanus } \\
n=9^{\text {d }}\end{array}$ \\
\hline \multicolumn{4}{|l|}{ Pennate Diatoms } \\
\hline Diploneis sp. & 4 & - & - \\
\hline Gomphonema sp. & 11 & - & - \\
\hline Licmophora sp. & 4 & - & - \\
\hline Navicula spp. & 11 & 10 & - \\
\hline Nitzschia ${ }^{e}$ & 96 & 100 & 100 \\
\hline N. cylindrus & 4 & - & - \\
\hline N. delicatissima & - & 3 & - \\
\hline N. frigida & 15 & 20 & - \\
\hline N. grunowii & 78 & 87 & 78 \\
\hline N. longissima & 4 & - & - \\
\hline N. seriata & 48 & 64 & 44 \\
\hline \multicolumn{4}{|l|}{ Centric Diatoms } \\
\hline Chaetoceros $^{e}$ & 8 & 13 & - \\
\hline C. atlanticus & 4 & - & - \\
\hline C. borealis & - & 7 & - \\
\hline C. decipiens & 4 & 13 & - \\
\hline C. socialis & 4 & - & - \\
\hline Coscinodiscus sp. & 15 & 7 & - \\
\hline Melosira arctica & - & 3 & - \\
\hline Thalassiosirae & 11 & 23 & 11 \\
\hline$T$. gravida & - & 3 & - \\
\hline$T$. nordenskioeldii & 7 & 10 & 11 \\
\hline Microflagellates & 15 & - & - \\
\hline
\end{tabular}

${ }^{a}$ Diet data are from Wellington Channel collections (fide $\mathrm{H}$. Stallard).

b The 27 samples consisted of 10 adult female, 9 stage $\mathrm{V}$, and 8 stage IV copepod stomachs.

'The 30 samples consisted of 11 adult female, 10 stage $V$, and 9 stage IV copepod stomachs.

d The 9 samples each consisted of 5 adult females.

'Includes unidentified species.

Parathemisto the ice-associated amphipods taken by murres in 1978 were larger than in 1976.

The decrease in mean estimated dry weight of total stomach contents from 1978 to 1979 at Pond Inlet (MannWhitney $P=0.002$ ) occurred primarily through further reductions in the numbers and dry weights of cod ingested. Ice-associated amphipods and, especially, Parathemisto were more importatnt in murre diets in 1979, but the small sizes of the major alternate prey taxa apparently prevented murres from compensating for the decreased importance of cod in the diet.

Abundances of under-ice amphipods (Cross, 1982) and arctic cod (Bradstreet, 1982) were different under smooth and rough ice. Ice type, however, was apparently not a factor influencing the diets of murres in 1978 or 1979.

\section{Ringed Seal Diet}

Near the ice edge the diet of adult ringed seals and narwhals was composed primarily of arctic cod. Amphipods and copepods may also have been consumed in small numbers by ringed seals, but the smallest of these invertebrates (especially copepods) likely came from the stomachs of the ingested cod. Invertebrates and especially Parathemisto were relatively more important to immature than to adult seals. In other areas invertebrates are known to be voided in feces, so observed differences probably were not due to the different types of samples obtained from immature (stomachs) and older (feces) seals.

McLaren (1958) found that in inshore waters ringed seals fed on benthic or epibenthic organisms such as mysids, arctic cod and decapods, while on landfast ice along southeast Bathurst Island, Parathemisto spp., Onisimus spp., mysids and small numbers of arctic cod were found in seal feces, and on the offshore pack ice in NW Baffin Bay, diets were dominated by Parathemisto spp. and also included seasnails (Cyclopteridae) and arctic cod (K.J. Finley, LGL Ltd., pers. comm.). Differences in location (inshore, offshore) thus do not totally explain the observed differences in diets. Age-related differences in the diets of ringed seals may account for some of the variability noted among studies.

\section{Arctic Cod Diet}

In the present study, differences were found between diets of inshore and offshore cod, both in quantities consumed and in relative abundances of the various prey taxa. The arctic cod collected offshore consumed mainly calanoid copepods and Parathemisto spp.; harpacticoid copepods and mysids were also important in terms of numbers and dry weight, respectively. The diet of inshore cod was also dominated by calanoid copepods; harpacticoid copepods and gammarid amphipods were also important in terms of numbers, whereas gammarid amphipods and mysids ranked second and third, respectively, in terms of dry weight (Table 3). Other studies have shown that epibenthic invertebrates such as mysids and amphipods form the majority of the diet of arctic cod in inshore waters (e.g. Moskalenko, 1964; Craig and Haldorson, 1981; Lowry and Frost, 1981). The few previous studies of arctic cod diet from deep offshore waters (Hognestad, 1968; Bohn and McElroy, 1976; Frost et al., 1978) found copepods to be the major food items.

The diet of cod collected in both inshore and offshore locations at Pond Inlet was apparently influenced by the presence of ice. Calanoid copepods and Parathemisto spp. were apparently not associated with the ice, but harpacticoid and cyclopoid copepods, mysids and all of the gammarid amphipod species found in cod stomachs were observed to be closely associated with the ice undersurface in Pond Inlet (Cross, 1982). The relatively greater importance of amphipods to nearshore cod may be attributable to their availability in two habitats (benthic, under-ice) in shallow water (see also Bradstreet, 1980), or to increased abundance of amphipods under inshore ice. Age-related differ- 
TABLE 8. Fat and energy content of selected food taxa

\begin{tabular}{|c|c|c|c|c|c|c|c|}
\hline \multirow[b]{2}{*}{ Taxon } & \multicolumn{3}{|c|}{ Fat content } & \multirow{2}{*}{$\begin{array}{c}\text { Energy content }^{\mathrm{a}} \\
\mathrm{X} \mathrm{kcal} \cdot \mathrm{g} \text { (dry weight) } \\
\pm \mathrm{SD}(n)\end{array}$} & \multicolumn{3}{|c|}{ No. items containing $100 \mathrm{kcal}^{\mathrm{b}}$} \\
\hline & Month & $\begin{array}{c}\% \text { of dry } \\
\text { weight }\end{array}$ & Source & & $\begin{array}{c}\text { No. } \\
\text { items }\end{array}$ & $\begin{array}{c}\text { X length } \\
(\mathrm{mm})\end{array}$ & Source \\
\hline \multicolumn{8}{|l|}{ Fish } \\
\hline \multirow{2}{*}{ Boreogadus saida } & Feb & $23-26$ & & & 32 & 76 & murres $1976-79$; this study \\
\hline & Nov & 32 & Yudanov (1964) & $6.024 \pm 0.533(10)$ & 12 & 102 & adult seals 1979 ; this study \\
\hline \multicolumn{8}{|l|}{$\begin{array}{l}\text { Ice-associated } \\
\text { amphipods }\end{array}$} \\
\hline \multirow[t]{2}{*}{ Onisimus spp. ${ }^{\mathrm{c}}$} & Oct & 40 & & & & & \\
\hline & Nov & 34 & Lee (1975) & $5.787 \pm 0.274(5)$ & 3045 & 10 & murres 1976; Bradstreet (1980) \\
\hline Apherusa glacialis & Oct & 24 & Lee (1975) & $5.961 \pm 0.785(7)$ & 5266 & 10 & guillemots 1976; Bradstreet (1980) \\
\hline Gammarus wilkitzkii & Nov & 26 & Lee (1975) & - & - & - & - \\
\hline \multicolumn{8}{|l|}{ Zooplankton } \\
\hline \multirow[t]{4}{*}{ Calanoid copepods ${ }^{d}$} & Jun & 29 & & & & & \\
\hline & Aug & 74 & & & & & \\
\hline & Dec & 51 & & & & & \\
\hline & Apr & 38 & Lee (1974) & $6.537 \pm 0.834(7)$ & 34528 & 7 & fulmars 1979; this study \\
\hline \multirow[t]{3}{*}{ Parathemisto spp. ${ }^{\mathrm{e}}$} & & & & & 982 & 22 & murres $1976 ; 1979$; this study \\
\hline & Feb & 19 & & & 415 & 30 & murres 1978 ; this study \\
\hline & Nov & 32 & Lee (1975) & $5.392 \pm 0.077(4)$ & 771 & 24 & immature seals 1979 ; this study \\
\hline
\end{tabular}

aanergy values determined from microbomb calorimetry of frozen items collected by LGL Ltd. in July-September in Barrow Strait-Lancaster Sound, N.W.T., and near Simpson Lagoon, Alaska. $n=$ number of separate energy determinations.

${ }^{b} 100 \mathrm{kcal}$ equivalent $=100 \cdot$ [dry weight value of an item of mean length (following Bradstreet, 1980; Table 2) $\cdot$ energy content] ${ }^{-1}$.

${ }^{c}$ Fat content from $O$. nanseni; energy content from $O$. glacialis.

${ }^{\mathrm{d}}$ Fat content from Calanus hyperboreus; energy content from Calanus spp. (mostly $C$. hyperboreus).

'Fat content from $P$. abyssorum; energy content from Parathemisto spp. (mostly P. libellula).

ences in diet, however, may also be a factor. Higher relative abundances of harpacticoid and cyclopoid copepods in the diets of one-year-old cod in both habitats may indicate that these fish rely more on non-selective feeding at the under-ice surface. Evidence of size selectivity in feeding of offshore cod on copepods and inshore cod on amphipods (i.e. larger fish consume larger prey) may indicate that older fish make more frequent excursions to the water column or bottom for the purpose of feeding.

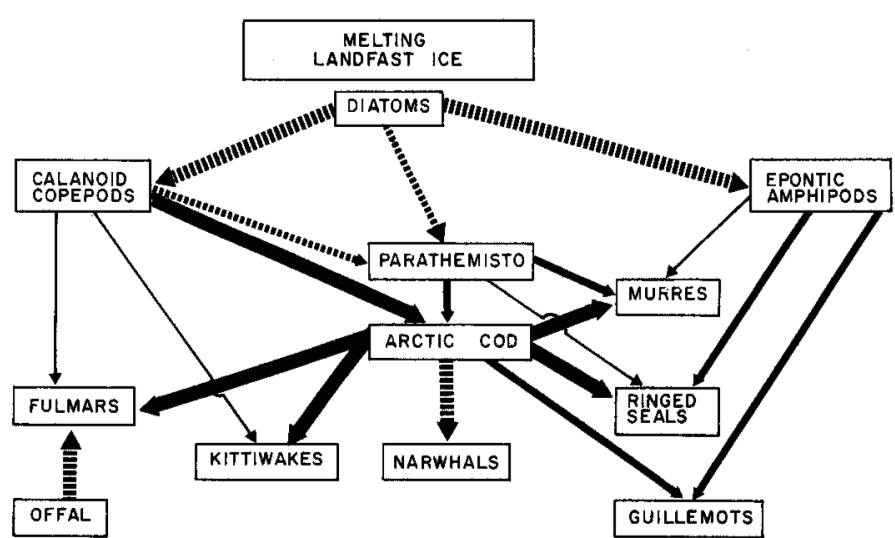

FIG. 4. Trophic pathways along offshore ice edges in the Canadian High Arctic. Decreasing widths of lines reflect pathways of major, moderate, and minor importance, respectively. Solid lines are based on dry weight analysis methods. Hatched lines are based on wet weight (narwhal) or occurrence (all other) analyses. Data for black guillemots (Cepphus grylle) and black-legged kittiwakes (Rissa tridactyla) are from Bradstreet (1980 and unpublished).

\section{Invertebrate Diets}

All of the species of microalgae consumed by amphipods in all three years were included in the ice microalgal community reported for Pond Inlet in 1979 by Cross (1982). Futhermore, pennate diatoms, particularly the genera Nitzschia and Navicula, dominated both the under-ice microalgae (Cross, 1982) and the diets of all of the invertebrates examined in the present study. The under-ice algal community has a similar species composition in other arctic locations (e.g., Hsiao, 1979a,b,c; Horner, 1977) and is quite distinct in species and group composition from the planktonic microalgal community. For example, Horner (1977) noted that pennate diatoms were dominant during bloom conditions in the undersurface of landfast ice at Barrow, Alaska, but at the same time centric diatoms and Phaeocystis pouchetti were dominant in the water column. During the period when the landfast ice is melting, however, ice algae apparently are released to the water column but do not continue to photosynthesize (Clasby et al., 1973). Cross (1982) observed macroscopic detrital masses that were evenly distributed in the water column under the ice in Pond Inlet during ice melt (June); these probably were fragments of sloughed-off ice algae. It is clear that the amphipods whose diets were examined in this study were consuming ice microalgae, and that these algae are available in concentrated forms both on the undersurface of the ice and in the water column, at least in June. Copepods collected in June at the Wellington Channel ice edge 
also consumed ice microalgae, but their diets also included two species of centric diatoms (Chaetoceros atlanticus and C. socialis; Table 7) that have not been found in the ice by Horner (1977), Hsiao (1980), or Cross (1982).

The similarity in species composition between the Pond Inlet ice algal community and the stomach contents of the amphipods collected there in 1979, and in particular the dominance of Nitzschia grunowii and N. frigida in both, indicates that these amphipods were feeding non-selectively on ice microalgae. Onisimus glacialis most often occurred in the bottom layer of ice (Cross, 1982), and it was often observed within small pockets or tunnels of clear ice surrounded by brown (diatom-rich) ice. Apparently it fed directly within the ice; the greater number of algal species in its diet may reflect this feeding method. Juvenile Onisimus have also been seen in large swarms on the soft, brown under-ice surface in the central Arctic, leaving a path of clear ice in their wake (W.E. Cross, pers. obs.), and Onisimus litoralis has also been observed on brown ice, apparently feeding (Horner, 1972).

The relatively low overlap between the diets of $O$. glacialis and Apherusa glacialis, and the smaller number of species consumed by the latter, may be related to habitat or feeding method. Apherusa was most commonly associated with masses of sloughed-off ice algae (Cross, 1982) that may have differed from the attached algal community in species composition. No feeding observations are available for Gammarus wilkitzkii, but this large omnivorous amphipod likely also consumed these concentrated masses of ice algae. This species was also observed on the ice undersurface, apparently feeding, by Horner (1972).

Calanoid copepods were not observed in close association with the ice in Pond Inlet, and Parathemisto libellula was seen near the ice only at one station in May. The primary source of the ice algae in the diets of these planktonic crustaceans was likely the fragmented, sloughed-off ice algae in the water column. These algae probably are dispersed into the water column with a vertical gradient of high cell densities in surface waters and lower densities in deeper waters. If so, this high concentration of diatoms in near-surface waters under landfast ice may, in part, explain the concentration of calanoid copepods and Parathemisto libellula in the upper water column that was reported at the Wellington Channel ice edge by Bradstreet (1980). $P$. libellula may also concentrate near the surface to eat copepods, an important component of the crustacean portion of its diet in spring (Wing, 1976). During May-June in southwestern Alaska the diet of Parathemisto libellula contained microalgae (in $30 \%$ of 130 stomachs), but in the July-April period no algae were found in any of 367 stomachs (Wing, 1976). These results suggest a seasonal use of microalgae that may be related to its concentrated form in spring, both on the under-ice surface and in the water column.

\section{Importance of Epontic Community}

In arctic marine food chains, the importance of the epontic community is in part due to its contribution to total primary productivity. Probably of more significance, however, is extension of the grazing season of herbivores, and the concentration of food items preferred by or acceptable to invertebrates and vertebrates on or near a two-dimensional platform.

The ice algal bloom occurs prior to the phytoplankton bloom and the two events are "clearly separated in time" (Apollonio, 1965; see also Horner, 1977). Therefore, animals that utilize ice algae or its detritus can begin grazing before many phytoplankton are available. Lee $(1974,1975)$ has shown that many arctic zooplankton store energy (as lipids) during summer, when phytoplankton are available, and that lipid levels decrease through the fall and winter to their lowest annual levels in spring (Table 8). Arctic cod have a similar cycle of fat levels (Moskalenko, 1964; Yudanov, 1964). Energy stores can, however, be replenished fairly quickly. In Calanus hyperboreus the annual high in lipid levels occurs in August, only 2 mo after the annual low (Lee, 1974). Thus an extension of the grazing season from $\sim 2$ mo (duration of phytoplankton bloom in the Arctic) to $\sim 4$ mo (duration of epontic plus phytoplankton blooms) may allow considerably greater annual secondary productivity. At Pond Inlet, this early accumulation of energy was reflected in significant growth in three genera of ice-associated amphipods (Onisimus, Apherusa, Ischyrocerus) between mid-May and early July (Cross, 1982).

After the peak of the ice algal bloom, ice algae are released from the ice, and sink through the water column (Clasby et al., 1973; Horner, 1976, 1977) where they can be grazed by zooplankton. In this study, calanoid copepods and Parathemisto ate many species of diatoms that were characteristic of the ice algal community. Thus the grazing season of some zooplanton may also be extended by the ice algal bloom, and their total annual productivity increased commensurately.

Under landfast ice, high levels of organic production are concentrated at or near a two-dimensional inverted substrate or "ceiling" (Dunbar and Acreman, 1980). High densities of ice algae in the undersurface of the ice probably lead to a higher grazing efficiency of ice-associated herbivores than would be the case in a three-dimensional system (Alexander, 1974). Indeed, even the zooplankton that were important in the food chains studied concentrate in the upper water column near the undersurface of ice, perhaps to feed on ice algae (or its detritus) released to the water column. At least in some instances this ice algal detritus forms concentrated, macroscopic masses (Cross, 1982). Finally, arctic cod occur very near the ice undersurface (Bradstreet, 1982) where they feed on zooplankton and ice-associated taxa.

In summary, the high levels of organic production that are concentrated near the undersurface of landfast ice 
prior to the phytoplankton bloom are transferred to seabirds and marine mammals via a few key taxa (especially arctic cod). Of the higher vertebrates studied, only the ringed seal utilizes extensive areas of landfast ice. Other marine mammals and seabirds are restricted to open water for breathing and/or access to food. Therefore, the food resources found under landfast ice are directly available to most higher vertebrates only at the edges of landfast ice. This leads to annually recurrent concentrations of many seabirds and some marine mammals at ice edges in the Canadian Arctic.

\section{ACKNOWLEDGEMENTS}

This study was funded by Petro-Canada as part of the Baffin Bay Eastern Arctic Marine Environmental Studies program administered by the Department of Indian Affairs and Northern Development, Ottawa. We thank G. Glazier, P. Idlout, G. Koenig, R. Wallace, and, especially, Sandy Mackenzie and Howard Hume of Petro-Canada for support and help throughout this study.

Field studies were conducted by the authors and by J. Barrie, K. Finley, E. Gibb, T. Jackoosie, G. Johnston, J. Kristensen, K. Loftus, G. Miller, P. Mladenov, C. Risley, and R. Salter of LGL Ltd. P. Aglak, I. Akpaliapik, S. Attagootak, and I. Milton of Pond Inlet provided assistance in the field. M. Foy, E. Gibb, L. Orman, J. Poliacik, C. Risley, H. Stallard, D. Thomson, and G. Vickers of LGL Ltd. assisted with laboratory analyses. K.J. Finley and $\mathrm{H}$. Stallard provided information on narwhal and copepod diets, respectively. R.A. Davis, C. Holdsworth, M.A. McLaren and W.J. Richardson provided assistance in planning, statistical analyses, and report preparation.

\section{REFERENCES}

ALEXANDER, V. 1974. Primary productivity regimes of the nearshore Beaufort Sea, with reference to potential roles of ice biota. In: Reed, J.C. and Sater, J.E. [eds.]. The Coast and Shelf of the Beaufort Sea. Arlington: Arctic Institute of North America. 609-635.

ANDRIASHEV, A.P. 1970. Cryopelagic fishes of the arctic and antarctic and their significance in polar ecosystems. In: Holdgate, M.W. [ed.]. Antarctic Ecology. Vol. 1. London: Academic Press. 297-304.

APOLLONIO, S. 1961. The chlorophyll content of arctic sea-ice. Arctic 14:197-200.

1965. Chlorophyll in arctic sea-ice. Arctic 18:118-122.

BAIN, H., THOMSON, D., FOY, M. and GRIFFITHS, W. 1977. Marine ecology of fast-ice-edges in Wellington Channel and Resolute Passage, N.W.T. Unpublished report by LGL Ltd., Toronto, for the Polar Gas Project, Toronto. 262 p. [Available in Library, Arctic Institute of North America, University of Calgary, Calgary, Alberta T2N 1N4].

BELOPOL'SKII, L.O. 1957. Ecology of sea colony birds of the Barents Sea. Israel Program for Scientific Translations, Jerusalem (1961).

BOHN, A. and McELROY, R.O. 1976. Trace metals (As, Cd, Cu, Fe, and $\mathrm{Zn}$ ) in arctic cod, Boreogadus saida, and selected zooplankton from Strathcona Sound, northern Baffin Island. Journal of the Fisheries Research Board of Canada 33:2836-2840.

BRADSTREET, M.S.W. 1979. Thick-billed murres and black guillemots in the Barrow Strait area, N.W.T., during spring: distribution and habitat use. Canadian Journal of Zoology 57:1789-1802.

1980. Thick-billed murres and black guillemots in the Barrow Strait area, N.W.T., during spring: diets and food availability along ice edges. Canadian Journal of Zoology 58:2120-2140.

1982. Occurrence, habitat use, and behavior of seabirds, marine mammals, and arctic cod at the Pond Inlet ice edge. Arctic 35 (this issue).
CLARKE, M.R. 1962. The identification of cephalopod "beaks" and the relationship between beak size and total body weight. Bulletin of the British Museum (Natural History) Zoology 8:421-480.

CLASBY, R.C., HORNER, R. and ALEXANDER, V. 1973. An in situ method for measuring primary productivity of arctic sea ice algae. Journal of the Fisheries Research Board of Canada 30:835-838.

CRAIG, P.C. and HALDORSON, L. 1981. Beaufort Sea barrier islandlagoon ecological process studies: Final report, Simpson Lagoon. Part 4. Fish. In: Environmental Assessment of the Alaskan Continental Shelf, Final Report of the Principal Investigators, Vol. 7. NOAA, Boulder, Col. 384-678.

CROSS, W.E. 1982. Under-ice biota at the Pond Inlet ice edge and in adjacent fast ice areas during spring. Arctic 35 (this issue).

DAVIS, R.A., FINLEY, K.J. and RICHARDSON, W.J. 1980. The present status and future management of arctic marine mammals in Canada. Science Advisory Board of the N.W.T. Rep. No. 3. Dept. of Information, Yellowknife.

DUNBAR, M.J. and ACREMAN, J.C. 1980. Standing crops and species composition of diatoms in sea ice from Robeson Channel to the Gulf of St. Lawrence. Ophelia 19:61-72.

ENGLISH, T.S. 1961. Some biological oceanographic observations in the central North Polar Sea, Drift Station Alpha, 1957-1958. Scientific Report No. 15. Arlington: Arctic Institute of North America. 79 p.

FINLEY, K.J., DAVIS, R.A. and SILVERMAN, H. 1980. Aspects of the narwhal hunt in the eastern Canadian High Arctic. Report of the International Whaling Commission 30:459-464.

FISHER, J. 1952. The Fulmar. London: Collins.

FROST, K.J., LOWRY, L.F. and BURNS, J.J. 1978. Offshore demersal fishes and epibenthic invertebrates of the northwestern Chukchi and western Beaufort Seas. In: Environmental Assessment of the Alaskan Continental Shelf, Annual Report of the Principal Investigators. Dec. 1979. Vol. 1 - Receptors. NOAA, Boulder, Colorado. 231-353.

GOLIKOV, A.N. and AVERINCEV, V.G. 1977. Distribution patterns of benthic and ice biocoenoses in the high latitudes of the polar basin and their part in the biological structure of the world ocean. In: Dunbar, M.J. [ed.]. Polar Oceans. Calgary: Arctic Institute of North America. 331-364.

HAGERUP, O. 1926. Communities of birds of the northern Atlantic Ocean. Meddelelser Dansk Natur Forenings 82:127-151.

HOGNESTAD, P.T. 1968. Observations on polar cod in the Barents Sea. Rapports et Proces-Verbaux des Reunions Conseil International pour l'Exploration de la Mer 158:126-130.

HORN, H.S. 1966. Measurement of "overlap" in comparative ecological studies. American Nature 100: 419-424. '

HORNER, R.A. 1972. Ecological studies on arctic sea ice organisms. University of Alaska, Institute of Marine Science Rep. No. R72-17. $79 \mathrm{p}$.

1976. Sea ice organisms. Oceanography and Marine Biology $14: 167-182$

1977. History and recent advances in the study of ice biota. In: Dunbar, M.J. [ed.]. Polar Oceans. Calgary: Arctic Institute of North America. 269-283.

and ALEXANDER, V. 1972. Ecology and metabolism of sea ice organisms. Institute of Marine Science Report No. R72-60. University of Alaska, Fairbanks. 23 p.

HSIAO, S.I.C. 1979a. Sea ice microalgal data from Eclipse Sound, 1976 and 1977. Canadian Fisheries and Marine Service Data Rep. No. 131. $34 \mathrm{p}$.

1979b. Sea ice microalgal data from Eskimo Lakes, 1972 to 1974. Canadian Fisheries Marine Service Data Rep. No. 146. 43 p.

1979c. Phytoplankton and sea ice microalgal data from Frobisher Bay, 1971 to 1978. Canadian Fisheries and Marine Service Data Rep. No. $155.82 \mathrm{p}$.

1980. Quantitative composition, distribution, community structure and standing stock of sea ice microalgae in the Canadian Arctic. Arctic 33:768-793.

LEE, R.F. 1974. Lipid composition of the copepod Calanus hyperboreus from the Arctic Ocean. Changes with depth and season. Marine Biology 26:313-318. 
1975. Lipids of arctic zooplankton. Comparative Biochemistry and Physiology 51B:263-266.

LOWRY, L.F. and FROST, K.J. 1981. Distribution, growth and foods of arctic cod (Boreogadus saida) in the Bering, Chukchi, and Beaufort Seas. Canadian Field-Naturalist 95:186-191.

McALLISTER, D.E. 1975. Ecology of the marine fishes of arctic Canada. In: Proceedings of the Circumpolar Conference on Northern Ecology. Section 2. National Research Council of Canada, Ottawa. 49-65.

McLAREN, I.A. 1958. The biology of the ringed seal (Phoca hispida Schreber) in the eastern Canadian Arctic. Bulletin of the Fisheries Research Board of Canada No. 118.97 p.

McLAREN, P.L. 1982. Spring migration and habitat use by seabirds in eastern Lancaster Sound and western Baffin Bay. Arctic 35 (this issue).
McROY, C.P. and GOERING, J.J. 1974. The influence of ice on the primary productivity of the Bering Sea. In: Hood, D.W. and Kelley, E.J. [eds.]. Oceanography of the Bering Sea. University of Alaska, Institute of Marine Science Occ. Publ. No. 2. 403-421.

MOSKALENKO, B.K. 1964. On the biology of the polar cod Boreogadus saida. Voprosy Ikhtiologii 4:433-443. (English translation, Alaska Dept. of Fish and Game).

PALMER, R.S. 1962. Handbook of North American Birds. Vol. 1. New Haven and London: Yale University Press.

SALOMONSEN, F. 1950. The birds of Greenland. Copenhagen: Munksgaard.

WING, B.L. 1976. Ecology of Parathemisto libellula and P. pacifica (Amphipoda: Hyperiidea) in Alaskan coastal waters. Northwest Fisheries Center Processed Report, Seattle. 266 p.

YUDANOV, I.G. 1964. Food value of polar cod. Rybnoye khozaistvo 40(10): 69-70. (English translation No. 2050702, Dept. of Secretary of State, Canada). 